\title{
Rancang Bangun Website untuk Memeriksa Plagiat E-Journal Fakultas Kedokteran Universitas Palangka Raya
}

\author{
Widiatry $^{1}$, Nova Noor Kamala Sari ${ }^{2}$ \\ ${ }^{1,2}$ Teknik Informatika, Universitas Palangka Raya \\ Kampus UPR Tunjung Nyaho Jalan Yos Sudarso, Palangka Raya 73111 \\ widiatry@it.upr.ac.id ${ }^{1}$, novanoorks@it.upr.ac.id ${ }^{2}$
}

\begin{abstract}
Abstrak - Jurnal ilmiah berisi kumpulan artikel yang dipublikasikan secara periodik dan ditulis oleh ilmuwan atau peneliti untuk melaporkan hasil-hasil penelitian terbarunya. Masalah yang dihadapi oleh Fakultas Kedokteran Universitas Palangka Raya, jurnal dikumpulkan dan diperiksa secara manual serta penerbitannya masih berupa media cetak. Oleh sebab itu, penyelesaian masalah tersebut adalah dengan membangun sebuah website untuk memeriksa plagiat pada E-Journal Fakultas Kedokteran. Website ini menerapkan Algoritma Rabin Karp untuk mendeteksi plagiarisme pada abstrak. Tahapan metode penelitian yang digunakan dalam penelitian ini adalah : (1) pengumpulan dan analisis data yang dilakukan dengan cara studi pustaka dan observasi, (2) metode yang diterapkan adalah metode waterfall yang sudah dimodifikasi melalui analisis sistem, desain sistem, implementasi dan pengujian menggunakan blackbox testing. Dengan adanya Website untuk memeriksa plagiat pada E-Journal diharapkan dapat meningkatkan efektifitas Fakultas Kedokteran dalam melakukan pengelolaan jurnal yang terbit sehingga jurnal tidak perlu dicetak. Jurnal dapat diunduh dan diunggah melalui website ini dan fasilitas yang ada dapat pula membantu dalam mendeteksi plagiat sehingga kedepannya bisa menghasilkan jurnal dengan kualitas yang baik. Diharapkan untuk pengembangan dimasa akan datang, website ini dapat dikembangkan dengan menggunakan algoritma stemming untuk mendapatkan hasil perhitungan kemiripan yang lebih akurat dan memperhatikan kesalahan ejaan yang ada.
\end{abstract}

Kata Kunci - Algoritma Rabin-Karp, E-Journal, Plagiat

\section{PENDAHULUAN}

Jurnal sebagai salah satu hasil pengetahuan yang terwujud dan terangkum dalam tulisan-tulisan ilmiah memungkinkan siapa saja yang mempunyai karya tulis dapat memasukkan karyanya. Jurnal yang kita kenal biasanya berupa buletin atau majalah ilmiah yang diterbitkan oleh institusi teretentu dan bagi siapapun yang ingin mempublikasikan hasil karya ilmiahnya harus terlebih dahulu mengirim ke institusi tersebut untuk dipublikasikan. Terdapat beberapa kelemahan apabila jurnal ini masih dikembangkan dan dijalankan dengan cara konvesional yang berarti karya ilmiah dipublikasikan dalam bentuk buku saja, keterbatasan jurnal konvensional ini antara lain yakni terbatasnya karya ilmiah yang diterima dan membutuhkan proses seleksi yang lama, terbatasnya pendanaan dalam penerbitan jurnal tersebut karena publikasi harus dicetak dalam bentuk buletin atau majalah yang sangat jelas apabila semakin banyak dicetak maka diperlukan biaya yang tidak sedikit dan lebih mahal.

Pada Fakultas Kedokteran Universitas Palangka Raya, jurnal dari penulis dikumpulkan dan diperiksa secara manual, penerbitannya masih berupa media cetak dan tidak terdapat sebuah aplikasi untuk mengecek atau mengetahui apakah jurnal yang dikirimkan plagiat atau tidak.

Oleh karena itu, proses pencegahan dan pendeteksian merupakan cara yang dapat dilakukan untuk mengurangi plagiasi yaitu dengan menggunakan algoritma Rabin-Karp pada website E-Journal. Algoritma Rabin-Karp adalah algoritma multiple pattern search yang sangat efisien untuk mencari string dengan pola banyak. E-Journal tidak berarti menggantikan model jurnal konvensional, tetapi memperkuat jurnal tersebut melalui pengelolaan penulis, karya tulis dan tanggapan atas karya tersebut, bahkan sampai mendiskusikan secara tak terbatas.

Peneliti sebelumnya juga telah melakukan penelitian diantaranya Pengembangan Media Informasi Ruang Kuliah pada Fakultas Teknik Universitas Palangka Raya berbasis android dan LBS [1] dan Penerapan Algoritma Levenshtein Distance Untuk Pencarian Pada Sistem Informasi Perpustakaan Pada Fakultas Kedokteran Universitas Palangka Raya [2] yang dapat menambah pemahaman dalam menganalisis dan mendesain suatu sistem di lingkungan Universitas Palangka Raya. 


\section{METODE PENELITIAN}

Model yang digunakan website untuk memeriksa plagiat pada E-Journal Fakultas Kedokteran Universitas Palangka Raya adalah model Waterfall. Model Waterfall adalah model klasik yang bersifat sistematis dan berurutan dalam Rekayasa Perangkat Lunak. Model ini merupakan model yang paling banyak dipakai dalam Software Engineering (SE) dan pertama kali diperkenalkan oleh Winston Royce sekitar tahun 1970 [3]. Pada perkembangannya banyak bermunculan modifikasi-modifikasi dari model tersebut. Sehingga model yang digunakan pada penelitian ini merupakan model Waterfall yang modifikasi.

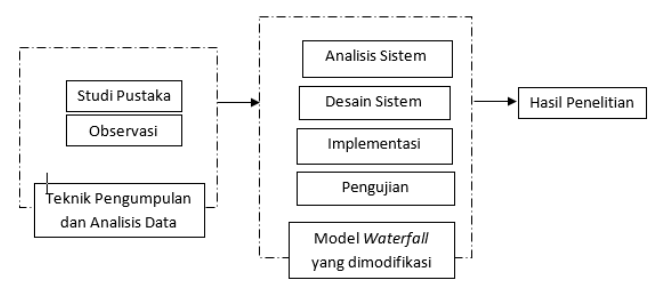

Gambar 1. Tahapan Penelitian

Berikut ini merupakan beberapa tahapan penelitian, yaitu:

1) Studi Pustaka dan Observasi

Metode ini melakukan studi pustaka terhadap buku, jurnal ilmiah nasional dan internasional sebagai pendukung dalam penelitian. Observasi dilakukan untuk mengambil datadata tentang jurnal pada Fakultas Kedokteran Universitas Palangka Raya.

2) Analisis Sistem

Proses pencarian kebutuhan difokuskan pada software untuk mengetahui sifat dari website yang akan dibuat, seperti manajemen hak akses pengguna beserta fasilitas-fasilitas yang ada, pemodelan proses bisnis menggunakan flowchart dan Unified Modeling Language (UML)

3) Desain Sistem

Proses ini digunakan untuk membuat "blueprint" software seperti, perancangan basis data dan perancangan antarmuka (interface).

4) Implementasi

Proses ini akan dilakukan pembuatan perangkat lunak sesuai dengan perancangan basis data dan antar muka yang telah dilakukan pada tahap sebelumnya.

5) Pengujian Sistem

Proses pengujian akan dilakukan dengan Blackbox Testing yang disertai dengan melakukan simulasi data.

\section{HASIL DAN PEMBAHASAN}

\section{A. Skenario Pengujian Algoritma Rabin Karp}

Algoritma rabin karp merupakan metode yang digunakan untuk mendeteksi plagiarisme. Pada tahap ini dilakukan analisa terhadap algoritma rabin karp. Dengan menentukan nilai $k$-gram dan basis primanya. Hasil dari hashing asli dan hashing uji kemudian dibandingkan untuk dicari hashing yang sama. Jika hashing yang sama ditemukan, maka dari hasil hashing yang sama tersebut dihitung tingkat persentase kesamaannya (similarity).

Berikut ini adalah contoh perhitungan kesamaan dokumen yang akan di proses dengan menggunakan metode Rabin Karp.

\section{Dokumen 1}

Glikasi merupakan reaksi ikatan antara glukosa dengan gugus amin pada protein atau lemak. Ekstrak etanol rimpang kunyit putih (Kaempferia rotunda Linn.) diyakini mampu menghambat reaksi glikasi karena memiliki kandungan flavonoid, kurkumin dan minyak atsiri yang berpotensi sebagai antiglikasi secara in vitro.

\section{Dokumen 2}

Diabetes Mellitus mempunyai gejala berupa peningkatan kadar glukosa darah(hiperglikemia).Tanaman serai wangi merupakan salah satu tanaman yang mampu menurunkan kadarglukosa darah.

Adapun langkah-langkah algoritma Rabin Karp yang akan dilakukan untuk mendeteksi plagiarisme adalah sebagai berikut [4]:

1. Tahapan Preprocessing yang terdiri dari case folding dan filtering

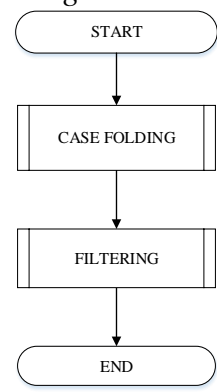

Gambar 2. Flowchart Preprocessing

a. Proses Case Folding

Proses case folding merupakan proses mengubah semua huruf menjadi huruf kecil.

b. Proses Filtering

Proses filtering yaitu proses membuang kata - kata yang tidak penting, membuang tanda baca dan membuang spasi.

\section{Tahapan Parsing K-Gram}

$K$-gram merupakan metode sebuah metode yang diaplikasikan untuk pembangkitkan kata atau karakter dengan memecah kata menjadi potongan potongan yang mengandung karakter sebanyak $k$. 


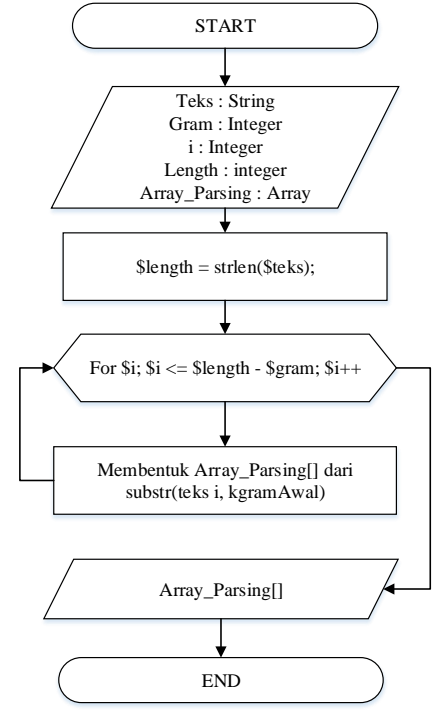

Gambar 3. Flowchart Parsing K-Gram

Berikut adalah proses parsing $k$-gram $k=7$ Hasil $k$-gram dokumen 1 yang telah melalui proses parsing k-gram

\{glikasi $\{$ likasim\} $\{$ ikasime $\}$ kasimer \{asimeru $\}$ simerup imerupa $\{$ merupak \{erupaka\} \{rupakan\} \{upakanr\} \{pakanre\} \{akanrea\} \{kanreak\} \{anreaks\} \{nreaksi $\{$ reaksii\} \{eaksiik\} \{aksiika\} \{ksiikat\} \{siikata\} \{iikatan\} \{ikatana\} \{katanan\} \{atanant\} \{tananta\} \{anantar\} \{nantara $\}$ antarag $\}$ \{ntaragl\} \{taraglu\} \{aragluk\} \{ragluko\} \{aglukos\} \{glukosa\} \{lukosag\} \{ukosagu\} \{kosagug\} \{osagugu $\}$ \{sagugus $\}$ angugusa \{ gugusam\} \{ugusami $\}$ gusamin $\}$ usaminp $\{$ saminpa \{aminpad $\}$ minpada $\}$ inpadap $\}$ \{npadapr $\}$ \{padapro\} \{adaprot \{daprote\} \{aprotei\} \{protein\} \{roteinl\} \{oteinle $\}$ teinlem\} \{einlema $\}$ inlemak $\}$ nnlemake\} \{lemakek\} \{emakeks \{makekst\} \{akekstr\} \{kekstra\} \{ekstrak\} \{kstrake\} \{straket\} \{traketa\} \{raketan\} \{aketano\} \{ketanol\}$\{$ etanolr $\}$ tanolri\} \{anolrim\} \{nolrimp $\}$ \{olrimpa $\}$ \{limpan $\}$ \{rimpang $\}$ \{impangk \{mpangku\} \{pangkun \{angkuny \{ngkunyi $\}$ gkunyit \{kunyitp\} \{unyitpu\} \{nyitput\} \{yitputi\} \{itputih\} \{tputihk \{putihka\} \{utihkae $\}$ tihkaem $\{$ ihkaemp\} \{hkaempf\} \{kaempfe \{aempfer\} \{empferi\} \{mpferia\} \{pferiar\} \{feriaro\} \{eriarot\} \{riarotu\} \{iarotun\} \{arotund $\}$ \{rotunda \{otundal $\}$ \{tundali\} \{undalin\} \{ndalinn $\}$ dalinnd $\}$ alinndi $\}$ linndiy $\}$ inndiya \{nndiyak $\}$ \{ndiyaki $\{$ diyakin $\}$ iyakini $\{$ yakinim $\}$ akinima \{kinimam $\}$ inimamp $\}$ nnimampu $\}$ imampum $\}$ \{mampume \{ampumen \{mpumeng \{pumengh \{umengha \{mengham \{enghamb \{nghamba\} \{ghambat $\}$ hambatr \{ambatre \{mbatrea\} \{batreak\} \{atreaks\} \{treaksi\} \{reaksig\} \{eaksigl\} \{aksigli\} \{ksiglik\} \{siglika\} \{iglikas\} \{glikasi\} \{likasim\} \{ikasime $\}$ kasimem $\}$ asimemi $\} \quad\{$ simemil $\} \quad\{$ imemili $\}$ \{memilik\} \{emiliki\} \{milikik\} \{ilikika $\{$ likikan\} \{ikikand \{kikandu\} \{ikandun\} \{kandung\} \{andunga\} \{ndungan\} \{dunganf\} \{unganfl\} \{nganfla\} \{ganflav $\{$ anflavo \{nflavon\} \{flavono $\{$ lavonoi $\}$ avonoid $\}$ vonoidk $\}$ \{onoidku\} \{noidkur

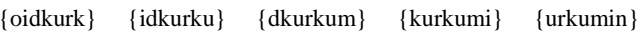
\{rkuminm $\}$ kuminmi\} \{uminmin $\}$ \{minminy $\}$ inminya \{nminyak $\{$ minyaka \{inyakat \{nyakats \{yakatsi\} \{akatsir\} $\{$ katsiri $\{$ atsirib $\{$ tsiribe $\}$ \{siriber $\{$ iriberp $\}$ \{riberpo $\}$ \{iberpot $\}$ \{berpote $\{$ erpoten\} \{rpotens $\}$ \{potensi\} \{otensia\} \{tensian\} \{ensiant $\}$ \{nsianti $\}$ siantig $\}$ iantigl $\}$ antigli $\}$ nntiglik $\}$ \{tiglika \{iglikas\} \{glikasi\} \{likasis\} \{ikasise $\}$ \{kasisec $\}$ \{asiseca \{sisecar $\}$ isecara $\}$ \{secarai $\}$ \{ecarain $\}$ \{carainv $\}$ arainvi \{rainvit\} \{ainvitr $\}$ invitro $\}$
Hasil k-gram dokumen 2 yang telah melalui proses parsing k-gram

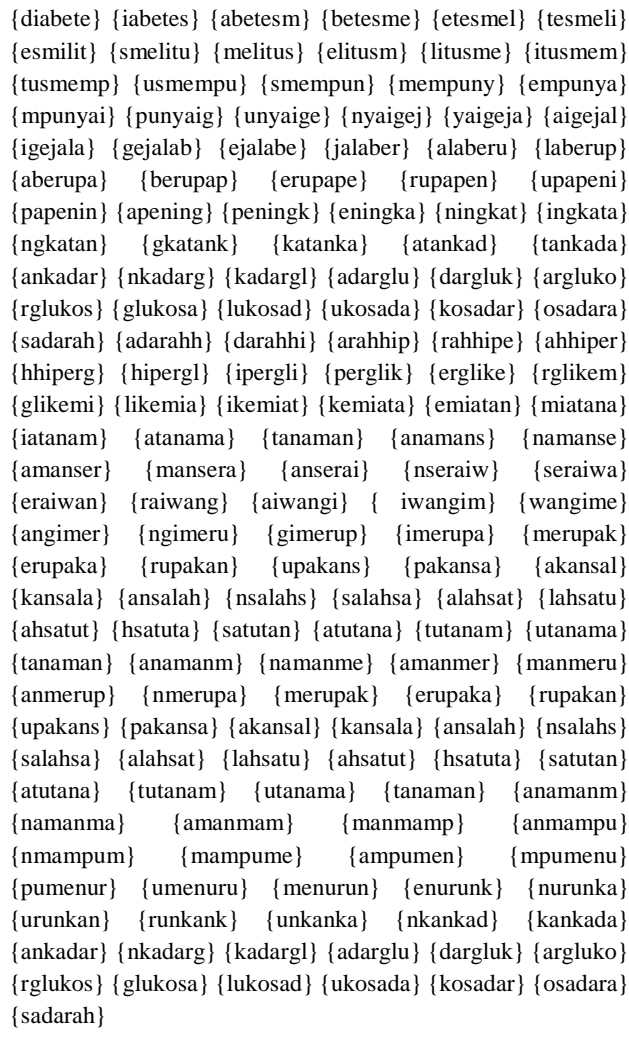

\{diabete $\{$ iabetes $\}$ abetesm\} \{betesme $\}$ etesmel\} \{tesmeli \{esmilit\} \{smelitu\} \{melitus\} \{elitusm\} \{litusme \{ itusmem\} \{tusmemp $\}$ \{usmempu $\}$ \{smempun $\}$ \{mempuny $\}$ \{empunya \{mpunyai $\}$ ppunyaig $\}$ \{unyaige $\}$ nnyaigej $\}$ yaigeja $\}$ a aigejal \{igejala $\{$ gejalab $\{$ ejalabe $\}$ jalaber $\}$ alaberu\} \{laberup \{aberupa $\}$ berupap\} \{erupape\} \{rupapen $\}$ upapeni\} \{papenin\} \{apening \{peningk $\}$ \{eningka $\}$ ningkat $\}$ ingkata \{ngkatan\} \{gkatank\} \{katanka\} \{atankad\} \{tankada \{ankadar\} \{nkadarg\} \{kadargl\} \{adarglu\} \{dargluk\} \{argluko \{rglukos $\}$ \{glukosa $\}$ \{lukosad $\}$ ukosada $\}$ knosadar $\}$ \{osadara \{sadarah\} \{adarahh\} \{darahhi\} \{arahhip\} \{rahhipe $\}$ ahhiper \{hhiperg\} \{hipergl\} \{ipergli\} \{perglik\} \{erglike\} \{rglikem \{glikemi $\{$ likemia $\}$ ikemiat $\}$ \{kemiata $\}$ emiatan $\}$ \{miatana \{iatanam $\{$ atanama $\}$ tanaman $\}$ anamans $\}$ namanse \{amanser $\}$ mansera $\}$ anserai $\} \quad$ nseraiw $\}$ \{seraiwa \{eraiwan\} \{raiwang \{aiwangi\} \{ iwangim\} \{wangime \{angimer\} \{ngimeru\} \{gimerup\} \{imerupa $\}$ merupak \{erupaka\} \{rupakan\} \{upakans\} \{pakansa\} \{akansal\} \{kansala\} \{ansalah\} \{nsalahs $\}$ \{salahsa \{alahsat \{lahsatu \{ahsatut $\{$ hsatuta $\}$ satutan $\}$ atutana \{tutanam $\}$ \{utanama \{tanaman\} \{anamanm\} \{namanme \{amanmer \{manmeru \{anmerup \{nmerupa $\}$ merupak \{erupaka $\}$ rupakan \{upakans\} \{pakansa\} \{akansal\} \{kansala\} \{ansalah\} \{nsalahs \{salahsa \{alahsat \{lahsatu\} \{ahsatut \{hsatuta \{satutan\} \{atutana $\{$ tutanam $\}$ utanama $\{$ tanaman\} \{anamanm \{namanma $\quad$ amanmam $\} \quad$ \{manmamp $\}$ anmampu \{nmampum $\quad$ \{mampume $\} \quad$ \{ampumen $\} \quad$ \{mpumenu \{pumenur\} \{umenuru\} \{menurun\} \{enurunk\} \{nurunka\} \{urunkan\} \{runkank \{unkanka $\}$ nkankad $\}$ kankada \{ankadar\} \{nkadarg\} \{kadargl\} \{adarglu\} \{dargluk\} \{argluko \{rglukos $\}$ \{glukosa $\}$ \{lukosad $\}$ \{ukosada $\}$ kkosadar $\}$ \{osadara \{sadarah\}

\section{Tahapan Hashing}

Proses hashing merupakan proses untuk mengkonvert setiap string menjadi bilangan. Dengan rumus

$H_{c 1 \ldots c k}=C_{1} \cdot b^{(k-1)}+C_{2} \cdot b^{(k-2)}+\cdots \cdots$

Contoh proses hashing untuk menghitung nilai hash dari kata $\{$ glikasi $\}$, dengan nilai $k=7$ dan $\mathrm{b}=7$. $\mathrm{H}=\left(103.7^{6}\right)+\left(108.7^{5}\right)+\left(105.7^{4}\right)+\left(107.7^{3}\right)+$ $\left(97.7^{2}\right)+\left(115.7^{1}\right)+\left(105.7^{0}\right)$

$\mathrm{H}=12117847+1815156+252105+36701+$ $4753+805+105=14227472$

Jadi, nilai hash pada dokumen 1 k-gram dari kata glikasi bernilai 14227472, proses perhitungan nilai hash diulang kembali hingga $k$-gram keseluruhan di hitung. Berikut ini adalah nilai hash dari dokumen 1 dan dokumen 2. 
Nilai Hash Pada Dokumen 1

\begin{tabular}{|c|c|c|c|c|c|}
\hline$\{14227472\}$ & $\{14767484\}$ & $\{14429845\}$ & $\{14537014\}$ & $\{13640114\}$ & $\{15597239\}$ \\
\hline$\{14473325\}$ & $\{14841367\}$ & $\{14123479\}$ & $\{15686620\}$ & $\{15922552\}$ & $\{15103434\}$ \\
\hline$\{13487319\}$ & $\{14527669\}$ & $\{13574697\}$ & $\{15139313\}$ & $\{15385566\}$ & $\{13815167\}$ \\
\hline$\{13528423\}$ & $\{14815406\}$ & $\{15588838\}$ & $\{14414531\}$ & $\{14429799\}$ & $\{14536688\}$ \\
\hline$\{13637831\}$ & $\{15581243\}$ & $\{13537827\}$ & $\{14881215\}$ & $\{13578878\}$ & $\{15168583\}$ \\
\hline$\{15590468\}$ & $\{13602395\}$ & $\{15333205\}$ & $\{13448648\}$ & $\{14256962\}$ & $\{14973908\}$ \\
\hline$\{15874829\}$ & $\{14769375\}$ & $\{15266641\}$ & $\{15453329\}$ & $\{13465955\}$ & $\{14378123\}$ \\
\hline$\{15822037\}$ & $\{14399838\}$ & $\{15974049\}$ & $\{15463909\}$ & $\{13540018\}$ & $\{14896552\}$ \\
\hline$\{14509789\}$ & $\{15096622\}$ & $\{15086735\}$ & $\{13370445\}$ & $\{13709545\}$ & $\{13574547\}$ \\
\hline$\{15404779\}$ & $\{15596745\}$ & $\{15293414\}$ & $\{15640734\}$ & $\{13954247\}$ & $\{14501993\}$ \\
\hline$\{15042037\}$ & $\{14704636\}$ & $\{15048764\}$ & $\{14751734\}$ & $\{13496065\}$ & $\{14588881\}$ \\
\hline$\{14003173\}$ & $\{14844469\}$ & $\{15792298\}$ & $\{15838738\}$ & $\{15340288\}$ & $\{13498225\}$ \\
\hline$\{14604012\}$ & $\{14109097\}$ & $\{15551641\}$ & $\{13570708\}$ & $\{15111397\}$ & $\{15190146\}$ \\
\hline$\{14917859\}$ & $\{15828172\}$ & $\{14493509\}$ & $\{14982665\}$ & $\{15112578\}$ & $\{13551351\}$ \\
\hline$\{14975891\}$ & $\{14241623\}$ & $\{14866522\}$ & $\{15946824\}$ & $\{15273353\}$ & $\{16323846\}$ \\
\hline$\{14618323\}$ & $\{15856353\}$ & $\{15463580\}$ & $\{16008345\}$ & $\{15703993\}$ & $\{14397075\}$ \\
\hline$\{14307612\}$ & $\{14504913\}$ & $\{13415404\}$ & $\{14024262\}$ & $\{14992088\}$ & $\{15178543\}$ \\
\hline$\{14013096\}$ & $\{14090402\}$ & $\{15455088\}$ & $\{14301824\}$ & $\{13640853\}$ & $\{15602397\}$ \\
\hline$\{15332985\}$ & $\{15917727\}$ & $\{15893211\}$ & $\{14898056\}$ & $\{13696762\}$ & $\{13523139\}$ \\
\hline$\{14778423\}$ & $\{14506414\}$ & $\{15072990\}$ & $\{14921305\}$ & $\{13859515\}$ & $\{14662410\}$ \\
\hline$\{16164964\}$ & $\{13472528\}$ & $\{14659432\}$ & $\{14497035\}$ & $\{15007347\}$ & $\{14461808\}$ \\
\hline$\{14760742\}$ & $\{13559117\}$ & $\{15030251\}$ & $\{15445674\}$ & $\{15882999\}$ & $\{14826571\}$ \\
\hline$\{14019908\}$ & $\{14961610\}$ & $\{14141656\}$ & $\{14166777\}$ & $\{13519068\}$ & $\{14749902\}$ \\
\hline$\{13483234\}$ & $\{13675539\}$ & $\{15845207\}$ & $\{15385564\}$ & $\{13815154\}$ & $\{13528340\}$ \\
\hline$\{14814816\}$ & $\{15584708\}$ & $\{14385626\}$ & $\{14227472\}$ & $\{14767484\}$ & $\{14429845\}$ \\
\hline$\{14537009\}$ & $\{13640067\}$ & $\{15596906\}$ & $\{14471002\}$ & $\{14825106\}$ & $\{14009660\}$ \\
\hline$\{14889884\}$ & $\{14463090\}$ & $\{14769781\}$ & $\{14445923\}$ & $\{14649563\}$ & $\{14427910\}$ \\
\hline$\{14523738\}$ & $\{13542162\}$ & $\{14946533\}$ & $\{14036389\}$ & $\{15900489\}$ & $\{14948989\}$ \\
\hline$\{14200609\}$ & $\{13548319\}$ & $\{14954952\}$ & $\{14095045\}$ & $\{14664034\}$ & $\{13705694\}$ \\
\hline$\{16056294\}$ & $\{15216101\}$ & $\{15099548\}$ & $\{15813107\}$ & $\{14337335\}$ & $\{13926570\}$ \\
\hline$\{14871875\}$ & $\{15984155\}$ & $\{15534663\}$ & $\{14858844\}$ & $\{15892917\}$ & $\{14896009\}$ \\
\hline$\{14505973\}$ & $\{15084565\}$ & $\{14899688\}$ & $\{14531745\}$ & $\{15250315\}$ & $\{16162180\}$ \\
\hline$\{13489431\}$ & $\{14542731\}$ & $\{13680114\}$ & $\{15877228\}$ & $\{15578852\}$ & $\{14559692\}$ \\
\hline$\{15413143\}$ & $\{14288215\}$ & $\{13545591\}$ & $\{14112033\}$ & $\{15366403\}$ & $\{15361724\}$ \\
\hline$\{15295349\}$ & $\{15654280\}$ & $\{14049128\}$ & $\{15165878\}$ & $\{15571519\}$ & $\{14293296\}$ \\
\hline$\{13581162\}$ & $\{15184570\}$ & $\{15702357\}$ & $\{14385626\}$ & $\{14227472\}$ & $\{14767490\}$ \\
\hline$\{14429887\}$ & $\{14537293\}$ & $\{13642047\}$ & $\{15610772\}$ & $\{14568056\}$ & $\{15504482\}$ \\
\hline
\end{tabular}

Jadi $\sum$ Hash $=228$

\section{Nilai Hash Dokumen 2}

$\{13802008\}\{14259871\}\{13347191\}\{13546767\}\{14120263\}\{15664106\}$ $\{14117859\}\{15647286\}\{13999646\}\{14819788\}\{14795973\}\{14629276\}$ $\{15933029\}\{16000332\}\{15647903\}\{14827997\}\{14029889\}\{15031485\}$ $\{15454311\}\{15943462\}\{15249809\}\{16159030\}\{13464615\}\{14368731\}$ $\{14109200\}\{13939572\}\{14399275\}\{13499484\}\{14612829\}\{13347256$ $\{13547233\}\{14123518\}\{15686893\}\{15924454\}\{15116757\}\{13580586\}$ $\{15180538\}\{14027047\}\{15011602\}\{14491581\}\{14969162\}\{14194511\}$ $\{14536745\}\{13638214\}\{15583924\}\{13556594\}\{15321590\}\{14498508\}$ $\{13370572\}\{13710440\}\{13618891\}\{15448681\}\{14256962\}\{14973905\}$ $\{15874788\}\{15874788\}\{14769099\}\{15264689\}\{15439654\}\{13370237$ $\{13708093\}\{13602463\}\{15333671\}\{13451909\}\{14279795\}\{14310201\}$ $\{14523040\}\{15189372\}\{14088889\}\{15444489\}\{14227626\}\{14768550\}$ $\{14437322\}\{14589336\}\{14006361\}\{14866781\}\{14301389\}\{13637805\}$ $\{15581074\}\{13536645\}\{14872945\}\{13520999\}\{14763419\}\{13577851\}$ $\{15161405\}\{15540202\}\{14074079\}\{15340813\}\{13501894\}\{14629696\}$ $\{15935958\}\{13550203\}\{14967867\}\{14185451\}\{14473325\}\{14841367\}$ $\{14123479\}\{15686620\}\{15922553\}\{15103437\}\{13487351\}\{14527883$ $\{13576184\}\{15149732\}\{15458491\}\{13502108\}\{14631202\}\{13475886\}$ $\{14447628\}\{15485034\}\{1368790\}\{15931668\}\{15990785\}\{15581074\}$ $\{13536639\}\{14872899\}\{13520672\}\{14761145\}\{13561945\}\{15050053\}$ $\{14760742\}\{13559117\}\{15030265\}\{15445782\}\{15883775\}\{14832004\}$ $\{14057948\}\{15227890\}\{16005610\}\{15684846\}\{15910117\}\{15016388\}$ $\{14525083\}\{13556594\}\{15012590\}\{14498508\}\{13370572\}\{13710440\}$ $\{13618891\}\{15448681\}\{14256962\}\{14973905\}\{15874788\}\{14769099\}$ $\{15264689\}\{15439654\}$

Jadi $\sum$ Hash $=146$
Hash Data 1 dan Data 2 yang Sama :

$\{14473325\}\{14841367\}\{14123479\}\{1558620\}$

$\{14256962\}\{1476074\}\{13559117\}$

Jadi $\sum$ Hash $=7$

4. Tahapan String Matching

Untuk menghitung kesamaan digunakan perhitungan similarity. Similarity didapat dari 2 kali hasil hash yang sama dibagi dengan jumlah hash kedua dokumen dikali dengan seratus persen.[5]

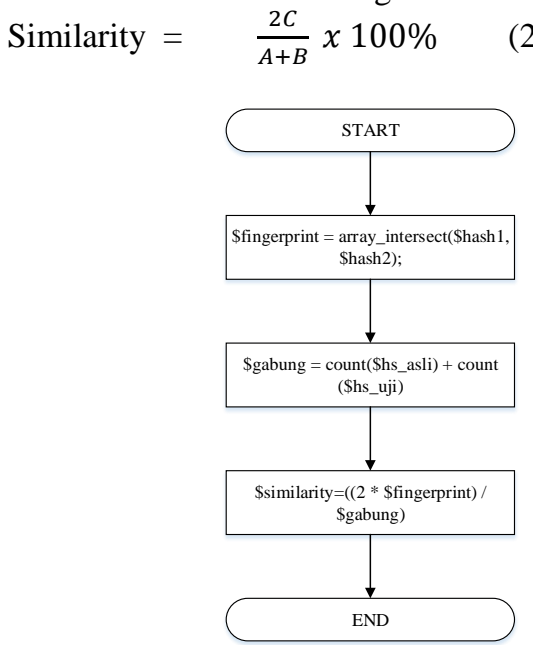

Gambar 4. Flowchart Similarity

Setelah dilakukan tahapan Preprocessing, Parsing K-Gram, dan Hashing di atas dapat dihitung kesamaan contoh dua dokumen dengan memasukkan ke rumus similarity

Similarity $=\frac{2 \times 7}{228+146} \times 100 \%=3,7 \%$

B. Hak Akses pada Website E-Journal

Manajemen hak akses pada Website E-journal Fakultas Kedokteran Universitas Palangka Raya akan dibagi menjadi 6 (enam) bagian, yaitu : Admin, Anggota FK UPR,Anggota Non FK UPR, Dewan Redaksi, Reviewer, Mitra Bestari

\section{Use Case Diagram}

Use case atau diagram use case merupakan pemodelan untuk kelakukan (behavior) sistem informasi yang akan dibuat. Use case mendeskripsikan sebuah interaksi antara satu atau lebih aktor dengan sistem informasi yang akan dibuat.[6] 
Jurnal CoreIT, Vol.5, No.2, Desember 2019

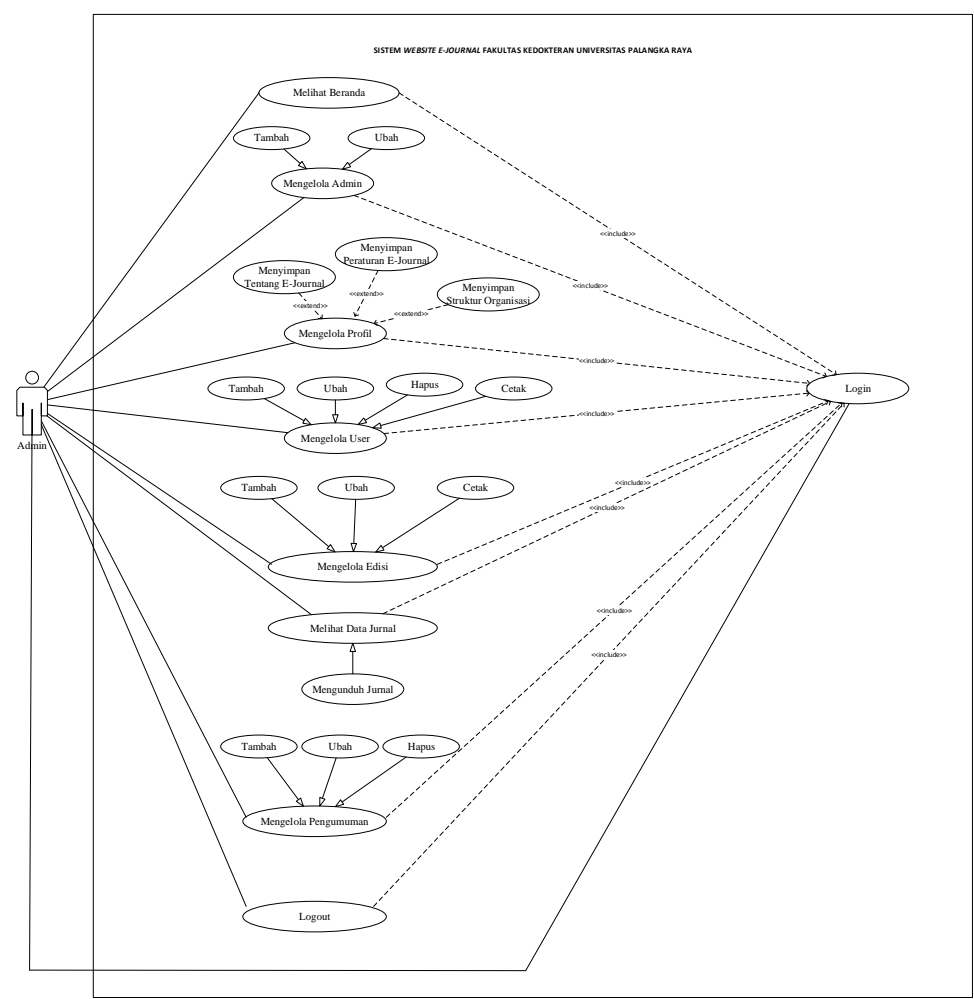

Gambar 5. Use Case Admin

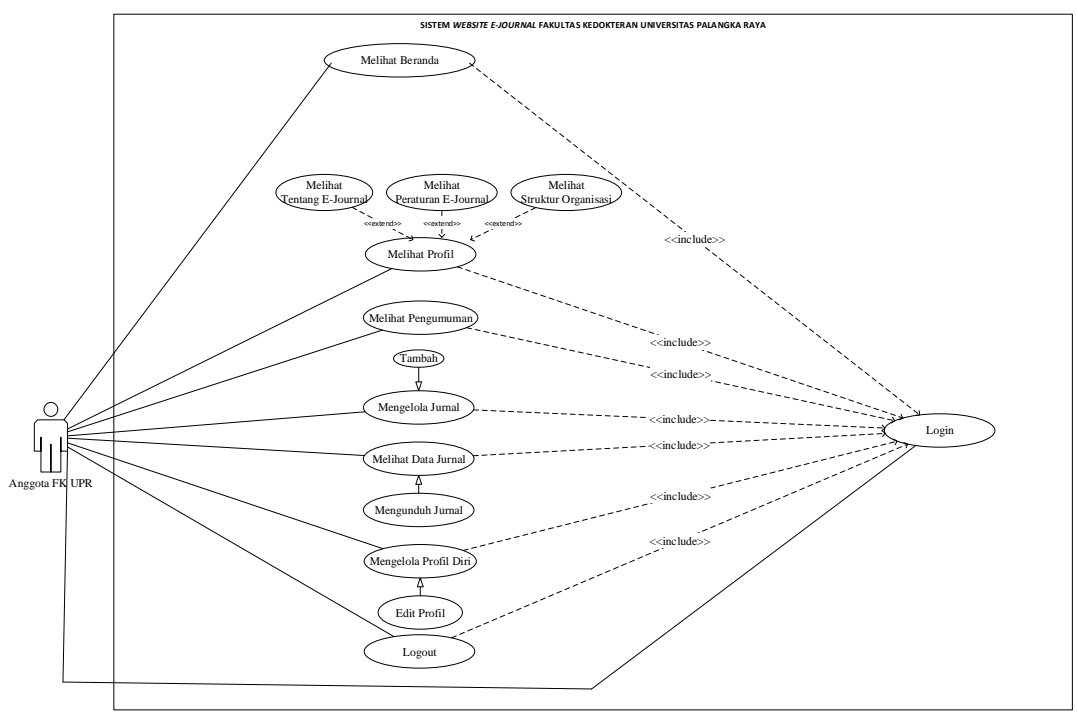

Gambar 6. Use Case Anggota FK UPR 


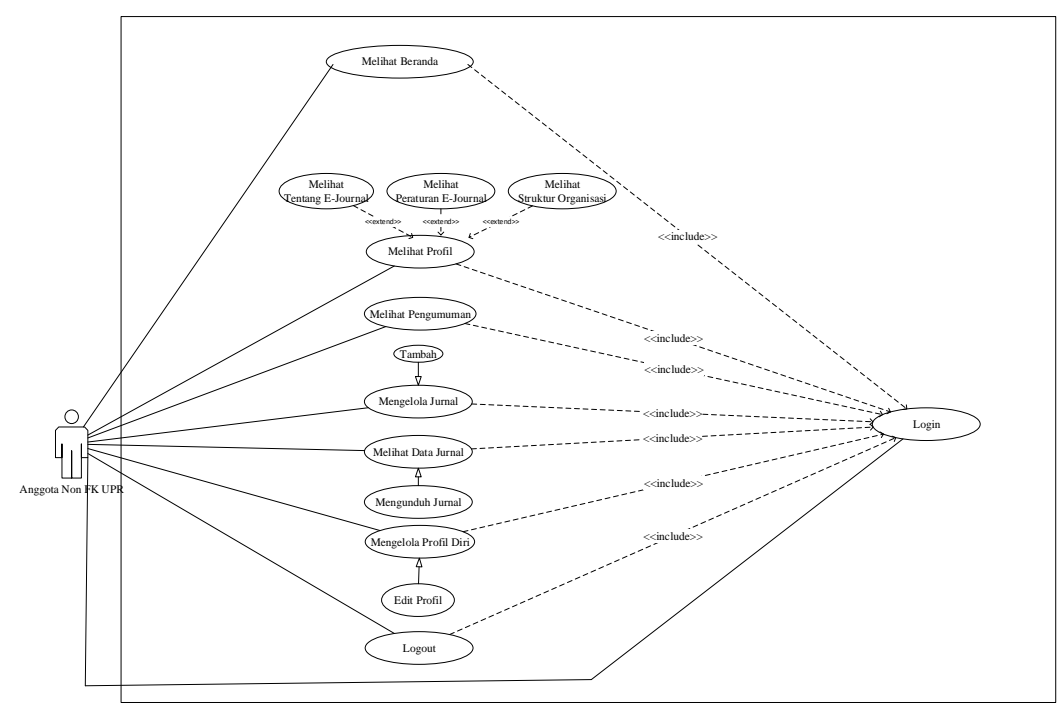

Gambar 7. Use Case Anggota Non FK UPR

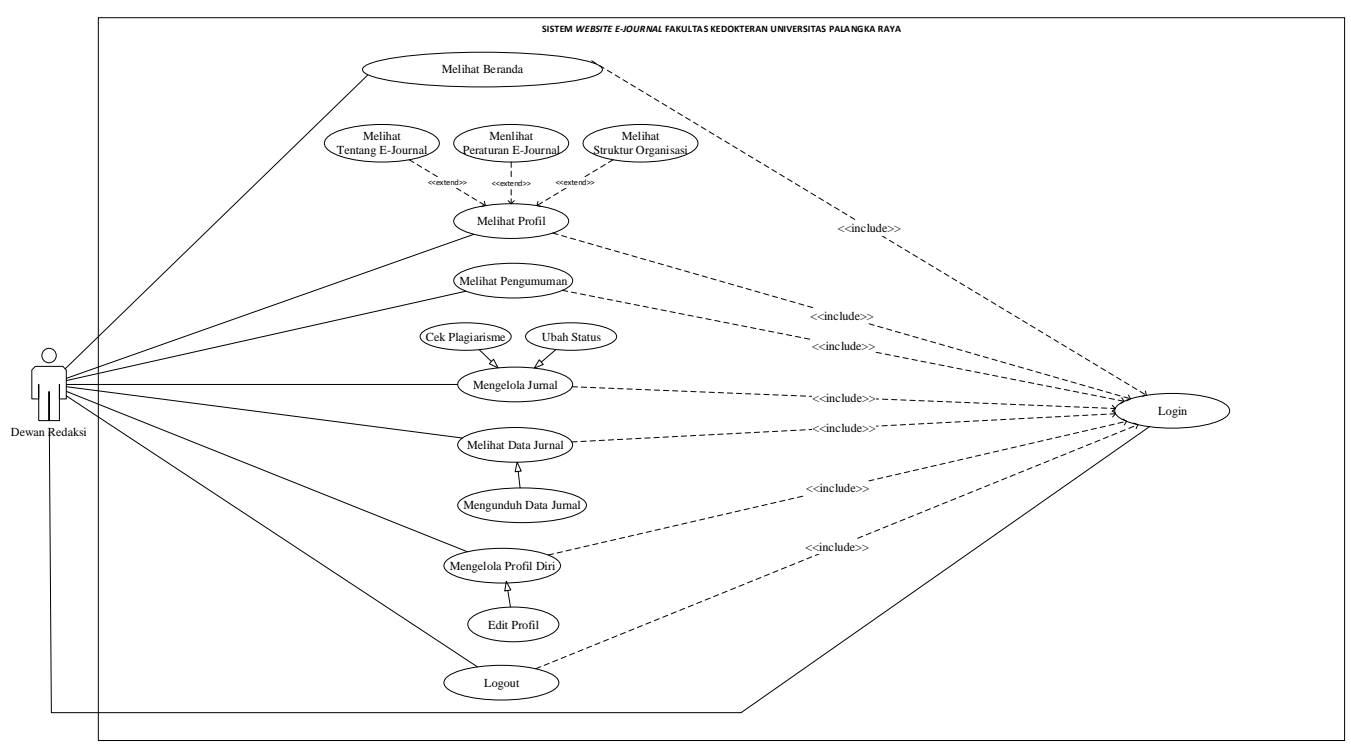

Gambar 8. Use Case Dewan Redaksi

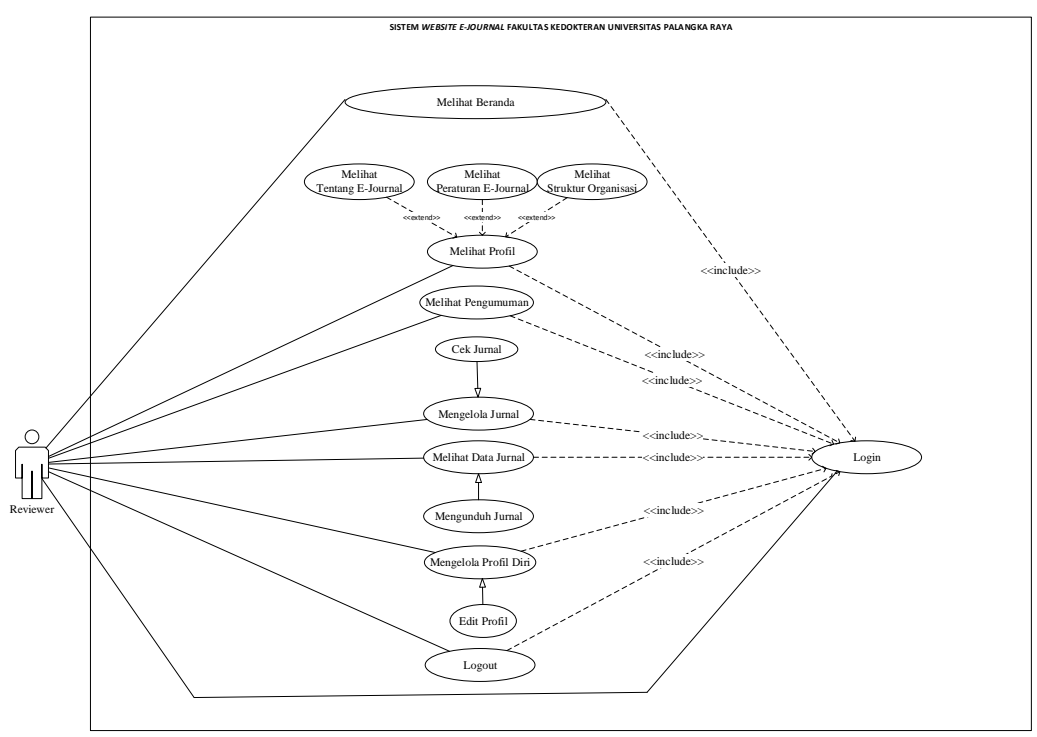

Gambar 9. Use Case Reviewer 


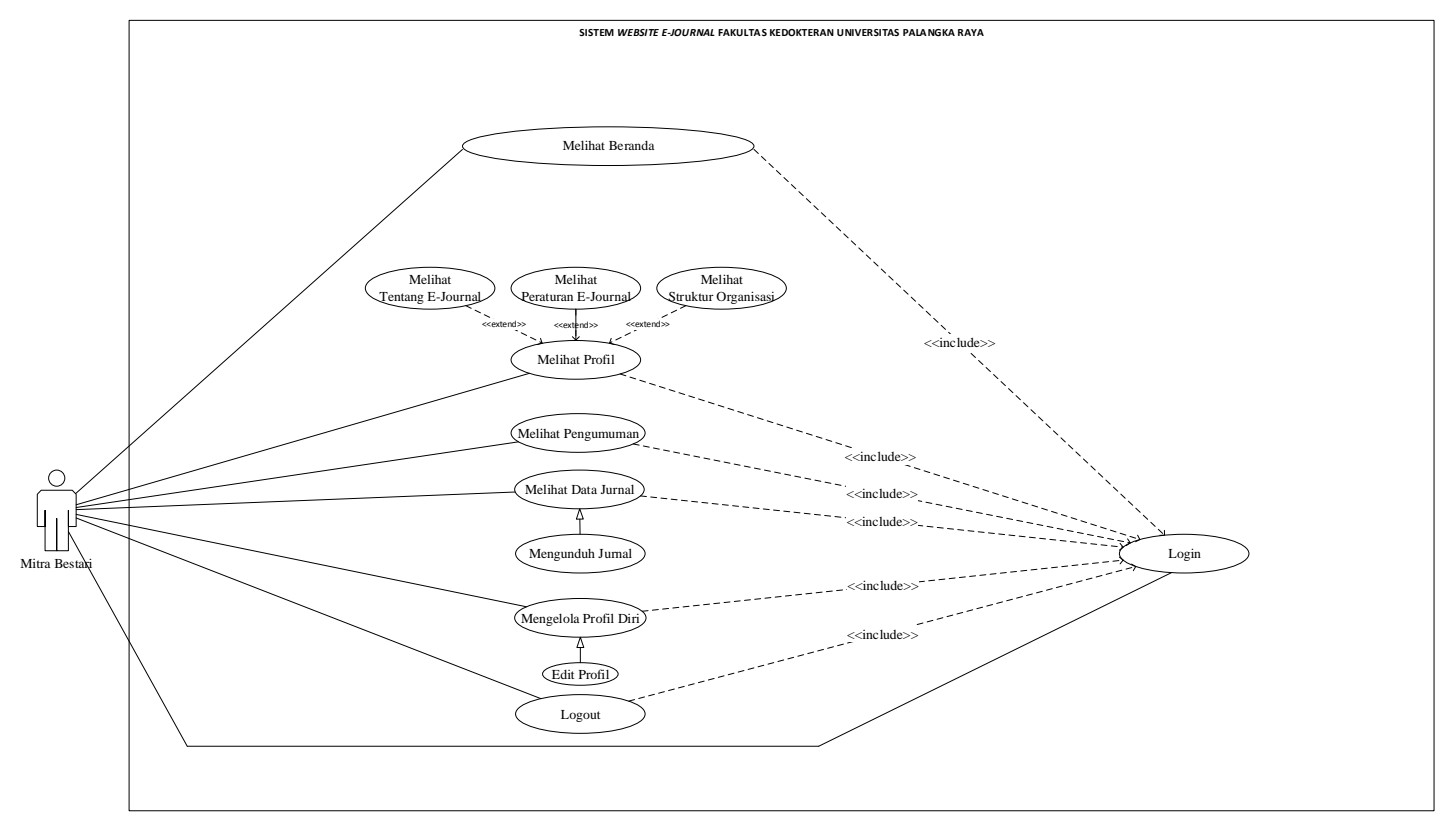

Gambar 10. Use Case Mitra Bestari

\section{Implementasi}

Fitur Menu Utama Admin

Pada gambar 11 merupakan beranda dan fitur -fitur yang terdapat pada halaman admin Website EJournal Fakultas Kedokteran Universitas Palangka Raya. Fitur - fitur yang ada pada halaman admin Website E- Journal Fakultas Kedokteran Universitas Palangka Raya yaitu beranda, kelola admin, kelola profil, kelola user, kelola edisi, data jurnal, kelola pengumuman dan logout.

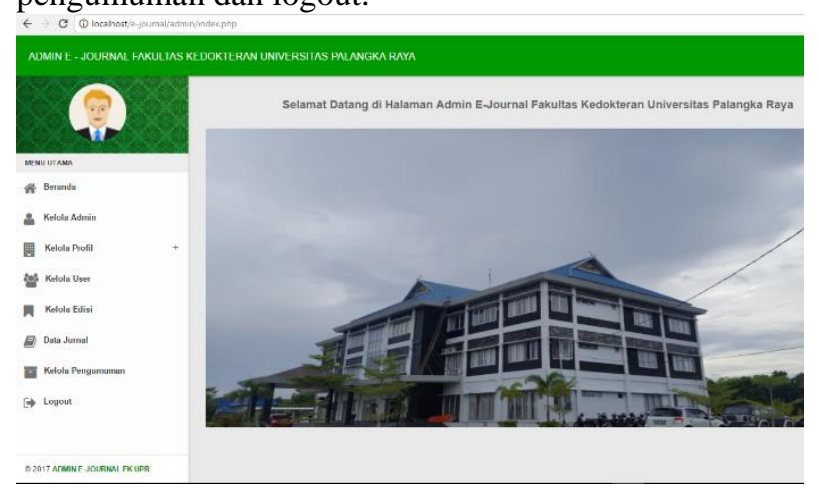

Gambar 11. Tampilan Menu Utama Admin

Fitur Menu Utama Dewan Redaksi

Pada gambar 12 merupakan beranda dan fitur -fitur yang terdapat pada halaman dewan redaksi Website E- Journal Fakultas Kedokteran Universitas Palangka Raya. Fitur - fitur yang ada pada halaman dewan redaksi Website E-Journal Fakultas Kedokteran Universitas Palangka Raya yaitu beranda, profil e-journal, pengumuman, kelola jurnal, data jurnal, kelola profil diri dan logout.

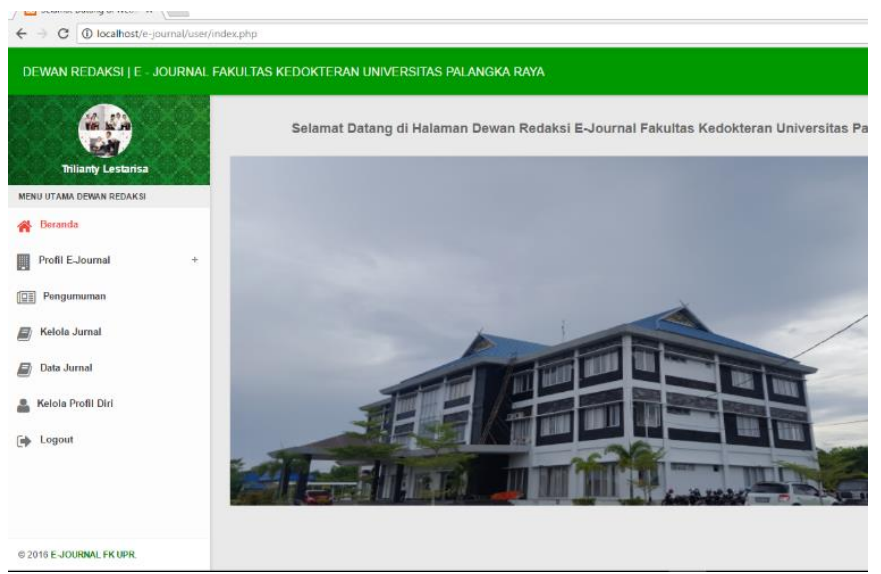

Gambar 12. Tampilan Menu Utama Dewan Redaksi

Fitur Kelola Jurnal

Fitur kelola jurnal merupakan fitur yang berfungsi untuk mengelola jurnal yang dikirimkan oleh anggota atau penulis jurnal yang sudah diseleksi oleh dewan redaksi. Pada fitur kelola jurnal ini reviewer berfungsi memberikan penilaian terhadap jurnal yaitu dengan cara menentukan jurnal tersebut diterima, ditolak dan di revisi. Pada gambar 13 adalah tampilan dari fitur kelola jurnal. 


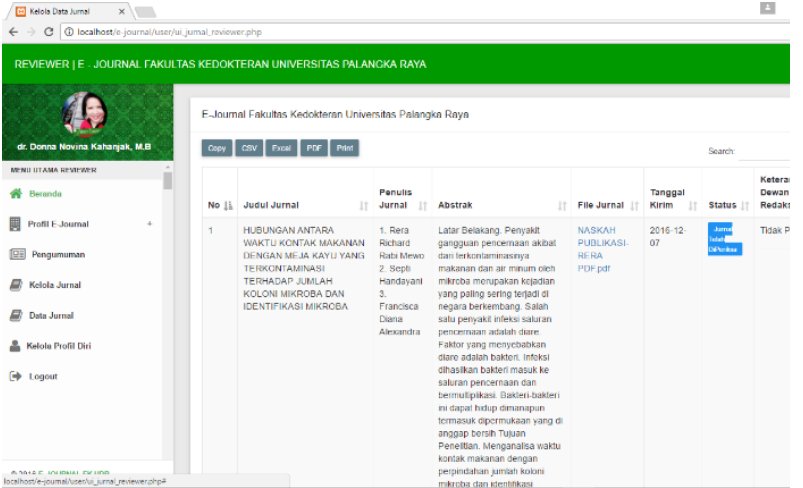

Gambar 13. Tampilan Fitur Kelola Jurnal Pada Reviewer

\section{KESIMPULAN DAN SARAN}

Kesimpulan yang dapat diambil adalah Pembuatan website E-Journal Fakultas Kedokteran Universitas Palangka Raya ini menerapkan Algoritma Rabin Karp untuk mendeteksi plagiat pada Jurnal. Model yang digunakan dalam pengembangan aplikasi ini adalah model Waterfall yang telah dimodifikasi. Langkah - langkah waterfall dalam metode ini yaitu tahap analisis, desain, implementasi dan pengujian.

Berdasarkan hasil uji dengan beberapa dokumen dapat disimpulkan bahwa algoritma Rabin Karp dapat digunakan untuk menghitung tingkat kemiripan sebuah abstrak. Perhitungan persentase kemiripan dihitung dengan menggunakan rumus Dice Coefficient Similarity.

Saran

Beberapa saran yang bertujuan untuk perbaikan atau peningkatan website ini yang diperlukan adalah :

1. Website ini dikembangkan hanya dengan menggunakan Algoritma Rabin Karp, diharapkan untuk pengembangan selanjutnya dapat menggunakan algoritma stemming untuk mendapatkan hasil perhitungan kemiripan yang lebih akurat.

2. Website ini tidak memperhatikan kesalahan ejaan sehingga diharapkan dapat dikembangkan dengan memperhatikan kesalahan ejaan.

\section{REFERENSI}

[1] N. N. K. Sari, "Pengembangan Media Informasi Ruang Kuliah Pada Fakultas Teknik Universitas Palangka Raya Berbasis Android dan Location Based Service," J. Teknol. Inf., vol. 13, no. 2, pp. 30-36, 2019.

[2] W. Widiatry, V. H. Pranatawijaya, N. N. K.
Sari, and P. B. A. A. Putra, "Penerapan Algoritma Levenshteindistance untuk Pencarian pada Sistem Informasi Perpustakaan Fakultas Kedokteran Universitas Palangka Raya," J. Saintekom, vol. 9, no. 1, pp. 66-82, 2019.

[3] S. Pressman, Roger, Rekayasa Perangkat Lunak.Pendekatan Praktisi. Edisi 7. Yogyakarta: Andi, 2012.

[4] S. Ramadhani, "Sistem Pencegahan Plagiarism Tugas Akhir Menggunakan Algoritma Rabin-Karp ( Studi Kasus : Sekolah Tinggi Teknik Payakumbuh )," $J$. Teknol. Inf. Komun. Digit. Zo., vol. 6, no. 1, pp. 44-52, 2015.

[5] B. Zaka, Theory and Applications of Similarity Detection Techniques. Graz University of Technology, 2009.

[6] R. A. S. and M. Shalahuddin, Rekayasa Perangkat Lunak Terstruktur Dan Berorientasi Objek. Bandung: Informatika, 2013. 
